\title{
Application of the doctrine of in loco parentis in the maintenance of discipline by secondary school principals in Delta State, Nigeria
}

\author{
Efeotor, I. E*, Dr. Kpee, G.G. \\ Department of Educational Management, Faculty of Education, University of Port Harcourt, Rivers State
}

*Corresponding Author: Efeotor, I. E, Department of Educational Management, Faculty of Education, University of Port Harcourt, Rivers State, Nigeria

\begin{abstract}
In child upbringing, parents serve as the first teacher of the child up to school age when the duties of parents are temporarily suspended and delegated to school teachers acting as psendo parents. It is against this background that this study investigated application of the doctrine of in loco parentis in the maintenance of discipline by secondary school principals in Delta State. Two objectives, two research questions and two hypotheses guided the study. The study adopted the descriptive survey design. The population of the study was 427 principals (242 males and 185 females) distributed over the 427 public secondary schools in the 25 Local Government Areas in Delta State. The sample size was 214 principals, comprising 124 males and 90 female principals serving in public secondary schools in Delta State. The multistage and proportionate techniques were used to draw the sample. The instrument used to generate data was a self-structured 16 items questionnaire titled 'Application of the Doctrine of in loco parentis in Maintenance of Discipline by School Principals Questionnaire' (ADIMDSQ). Test re-test was used to establish the reliability co-efficient of the instrument at 0.80. The research questions were answered using simple average mean statistics, while the hypotheses were tested at 0.05 significant level using the z-test. The study revealed that in loco parentis gave legal authority to principals to administer reasonable discipline on erring students. It also showed that in loco parentis required principals to take responsibility for moral and character developments of students in the school. Furthermore, this study recommended that government and Ministry of Education should regularly sensitize parents on the need for them to abstain from attacking principals and teachers when their children are reasonably disciplined in school
\end{abstract}

\section{INTRODUCTION}

Globally, organizations are established to achieve set goals. The school is an educational organization setup to facilitate the achievement of diverse developmental aspirations of the nation through the agency of education. This means that the quality of education children receives in school goes hand in hand with national development since children are priceless wealth of the nation and leaders of tomorrow. In Nigeria, secondary schools are instituted to afford young learners the opportunity to acquire additional knowledge, valuable skills and useful attitudes considered worthwhile for preparing them for fruitful adulthood, and for higher education (Federal Republic Nigeria [FRN], 2014). The attainment of the said secondary education goals is contingent on enabling environment (that mark resemblance of serene and conducive atmosphere) that permits cooperation among and between the school leaderships, teachers and students and parents.

It is important for educational practitioners to remember always that parents are the first teachers children learn from, and thus makes sense that parents and teachers requires a functional relationship anchored on the common goal of providing qualitative education to the child. Although parents and educators ought to join forces together in educating young learners, however in practice, this may not be tenable because of disagreement that may arise over who has a particular moral and legal roles and authority to perform important obligation such as discipline in school. Under Nigeria law, parents can discipline their children at home, but in the school, that duty is delegated to the school principal, head-teacher and teachers. Discipline helps to keep the school safe, orderly and effective; because in schools where the atmosphere is chaotic, teaching and learning will collapse, as no teacher will want to teach in an unsafe environment where rude and rowdy students may insult or assault his/her person.

Discipline is the process of learning self-control. It can also be viewed as training exercise geared towards enabling an individual to behave well and master their behaviours through self-control and restraint (Olaitan 
et al., 2013). Studies in psychology indicate that individuals are always inundated with positive and negative impulses demanding physical expression. In order to check these impulses, especially negative ones, laws are made to permit individuals to express wholesome impulses while containing the negative instincts. Hence, the process of restraining self from expressing certain impulses as they come to mind is known as discipline. In these views, discipline is more of moral guidance than punitive tool. This is because the ultimate aim of discipline is to reform or cause individual students to give up their respective bad behaviours and habits, in order that they may be replace with good habits that are consistent with and in obedience to school rules and regulations. Discipline helps students to learn patience, perseverance and determination to overcome daunting challenges they may encounter. Teaching students discipline also help them to understand early, the importance of exercising self-denial and restraint in dealing with people, one's impulses and situations. Some of the behaviours that mark discipline in students include honestly, fairness, truthfulness, good character and compassion, obedience, cooperation, selflessness and commitment, tolerance, integrity and diligence among other virtues.

Unfortunately, many students do not manifest the above mentioned indicators of discipline in the schools. Indiscipline is rather a common school problem nowadays. It is opposite of discipline. It has so many negative consequences on individual student, school and the society. Indiscipline is any behavioural problem that is contrary to social norms, laid-down school rules and regulations. They include lateness to school, absenteeism, fighting, stealing, dishonesty, rebellion and violent unrest, bullying, lying, etc. Ekanem and Edet (2013) identified the causes of students' indiscipline as unproductive teaching, lack of instructional facilities, lack of home training and moral deficit, unsafe learning environment, peer influence, and stringent school rules among others. School principals are statutorily required to maintain discipline in their respective schools in order to ensure smooth operation of school programmes.

Maintenance is simply sustenance; it is actions-driven activities geared towards keeping a given system functioning, or to cause an activity to endure. Maintenance of discipline is therefore the series of punitive and non-punitive actions taken by school principals for the purpose of preserving school traditions, routines and practices in order to promote peace and order necessary for conducive learning environment in the school. This can be done by ensuring that school employees and students perform their obligations in line with classroom routines, established work performance protocols, and by ensuring that students buy into obeying school rules and regulations that passed test of moral philosophy, common laws and constitution.

To achieve this, the school principals have to make sure that school rules and regulations are written in explicit language and communicated to students and school employees in a clear manner. Good knowledge one's rights, privileges, roles, expectations and duties in school is very essential if one must obey or comply with the reasonable rules. In other words, students need to be taught why they are in school, their obligations and reasonable penalties for deviation from reasonable expectations are necessary for ensuring peaceful school. Discipline is important because it helps to modifies students' behaviours and makes them to learn the virtue of obeying rules and regulations in the school and beyond the school compound.

The task of maintaining discipline in the school to foster instructional effectiveness is domicile within the functions of school principals, (also known as school administrators). Maintenance of discipline entails using different approaches to modify students' behaviours. The first approaches is non-punitive strategies such persuasion, encouragement, counselling, teaching with illustrations and presentations, scolding, etc. Second approach (often adopted when the strategies in the first approach proved ineffective) is punitive measures such as detention during school hours, corporal punishment, suspension and expulsion among others. Punitive measures such as corporal punishment are often considered handy by school principals, especially when the offence committed is grievous or callous. Callous offences such as fatal stabbing, killing and rape are too serious for the principal to handle alone; he/she may have to report such cases to law enforcement agencies to handle in synergy with the Ministry of Education.

Principals' power to instil discipline in students is widely recognized in national and common laws, most of which are encapsulated in the doctrine of in loco parentis. Nwabueze and Ihuoma (2018) remarked that school principals drive their power to discipline students from the doctrine of in loco parentis. In loco parentis is a Latin phrase that means 'in place or position of parents' in English translation. The doctrine is rooted in moral philosophy, and grounded on British Common Laws, which were introduced into Nigeria legal system by the colonial government. The doctrine confers powers on schools authorities to perform parental responsibilities such as educating students, caring for them and controlling their behaviours 
through discipline. Based on this, it is a legal duty and pedagogical responsibility of school principals to instruct, care, monitor and discipline students under their custody. The emphasis on discipline is based on the fact that children are naive and unlikely to behave well without training, hence the need to mould their behaviours using disciplinary approaches based on school code of conduct, existing education laws and directives from the Ministry of Education. In effect, this implies that principals have legal authority to administer discipline to correct students, in so far as the punishment is reasonable and commensurate to the offence so committed. On the other hand, teachers (under the doctrine of vicarious liability) may also use diverse non-punitive strategies to correct students when they contravene the school rules and regulations. The limit to such powers is to the degree it enables them to perform their administrative and instructional functions to attain education goals.

Although the 1999 Constitution of Federal Republic of Nigeria preserves fundamental human rights such as rights to liberty, freedom of movement, association, religion and so on, it however does not subvert the authority of parents 'to train up a child in the way he should grow; and when he is old, he will not depart from it', neither does it forbid the powers of school principals (under in loco parentis) to curtail some human rights where it becomes morally imperative and reasonably necessary to enable principals to perform their administrative and instructional functions. In fact, the said constitution reinforced the legitimacy and powers of school principals to discipline and administer punishment on students who defy the school rules and regulations, having specified that people's right to personal liberty may be restricted for educational and welfare purposes, especially in circumstances whereby an individual is still a child (and has not reached the age of eighteen years) (Federal Republic of Nigeria [FRN], 1999 Constitution, section 34 sub-section 1, 1999).

Students is secondary schools are mostly below the age of eighteen years however, school principals are limited by the extent they can stand in for parents in administration of discipline as may be forbidden by the constitution and judicial pronouncements. Nigerian judicial system exercise jurisprudence over educational matters and consider school principals and other officials as having taking the place of a loving parents and associated responsibilities, including helping children to modify and improve their behaviours through diverse reasonable approaches such as supervision, counselling, scolding, rebuking and reasonable corporal punishment. This presupposes that school principals stands in place of parents under the doctrine of in loco parentis to protect, students from all physical, psychological and spiritual harms, abuses and discriminations. It is on this ground that principals or school principals are constrained to make school rules and regulations that ought to help them in maintaining discipline in the school, by regulating and controlling students' and teachers behaviours towards students. Such rules and regulations have to be reasonable, justifiable and equitable in terms of penalties and mortification approaches. Hence, the rules have to be consistent with the constitution and marks resemblance of what a loving father would do to reclaim his delinquent child from destructive behaviours. This implies that courts cannot encroach on the authority of school principals to make rules with which to manage the school and control students' behaviours for effective school governance (Nakpodia, 2009). However, the court may intervene in only aspects of the rules or school policies that are unjustifiable and stand in conflict with the law.

With regard to the foregoing, it is important to notice that the society is changing so rapidly that many canons and doctrines such as that of in loco parentis are being interrogated afresh by some people. Some parents for instance have questioned the legality, and reasonability of the doctrine of in loco parents in the context of contemporary secondary schooling. They argue that the environment under which the said doctrine was inducted in Common Laws was relevant to the peculiar needs of schooling then than now, given that the mode of schooling has changed drastically. Alexander (1980) observed that (prior to middle ages), schools were few and run by voluntary institutions, whereby willing parents optionally sends their children to learn with their caring tutors all day, via interactions and literary development teachings, and by so doing develop close affinity, true bond and affection for each-other. It is believed in psychology, that such friendly relationship will by all means prompt the tutors to protect their students' interests and wellbeing at all cost. Interestingly, the situation has changed drastically, though some secondary schools still operate boarding schooling where greater care towards students is manifest, however greater numbers of secondary school are day schools, where educators instruct students for only few hours of the day, which may not be enough for them to bond and develop sufficient friendly relationship with the students to justify parental delegation of full parental responsibilities to the school authorities. 
Nene (2013) remarked that the situation under which the doctrine of in loco parentis was founded does no longer prevail anymore, hence the need to limit the scope of authority conferred on educators to administer corporal punishment on the student. It is important to remind those that are opposed to the doctrine of in loco parents to be in the know that the Nigerian courts view school officers from the standpoint of standing in loco parents. This is why in cases where a teacher or principal fails to protect a child under his/her care, and by peradventure the child gets injured, the teacher will not be excused if proven that he/she failed or neglected to care for the child. Such a teacher or aprincipal's fate will be adjudicated based on the doctrine of in loco parentis and tort liability implications.

It was therefore on this ground that Oosthuizen et al. (2002) remarked that educators cannot replace parents in whatever guise. The scholar argued that difference exists in terms of closeness of relationships between children, their parents and educators, noting that parents have closer relationship with their children and also exhibit more affectionate attitudes that rouse deep feeling of reciprocal love from the children. Such level of connection and bond is unlikely to develop between today's educators and students. This is not because educators are bad or incapable of developing such effectual bond, but because the modern schooling system only allows educators to meet intermittently with students during less than an hour instructions; a time too short for meaningful emotional connection and love to develop. It is on this grounds that teacher's use of corporal punishment, expulsion, detention, crawling, kneeling and other punitive methods of disciplining students is often frown at by many parents who consider them crude and too harsh for their lovely children. It is response to these arguments that various State Ministry of Education have being cautioning principals and other educators to avoid or reduce the use of punitive disciplinary approaches, and instead, explore non-punitive approaches such as exhortation, counselling, persuasions, inducements and reprimands among other knowledge-driven and psychoanalytic remedies.

It is perhaps for this reasons that some scholars such Ekanem and Edet (2013) suggested that corporal punishment hardens some students heart in wrong doings. Things may also go wrong when afflictive corporal punishment is used to coerce obedience on a student that did not properly understand the reason for the punishment; who thus sees it as a senseless and unjustifiable cruelty against his/her person. Such arbitrary and condemnable punishment is not only considered as abuse of in loco parentis and human dignity, but also as a repressive discipline that constitutes training in error, as such abuse may result in prolonged maladjustment problems on the part of the students (Van-Breda, 2014).

It is based on the latter reasons that the old Rivers State for instance, issued a circular prohibiting teachers (excluding principals) from administering any form of corporal punishment on students (Peretomode, 2004). The circular further marshalled out all the step-by-step processes principals are to follow to administer punitive discipline to recalcitrant and deviant student, especially when the non-punitive approaches to correct an erring student have been used unsuccessfully to effect desirable change in the child's behaviour. The truth is that punishments given by school officials and parents respectively are most likely received with different mind-sets even if the punishment was administered with best of intentions. Children are likely to accept punishments in good faith if it is coming from their parents, than when it is given by another person other than their parents, say the teacher. This is because students are likely to resent punishment coming from their teachers; especially if they think that such a teacher does not like them. This explains why some punishments are effective while others are not, the approach (punitive or non-punitive) notwithstanding.

It is against these criticisms and palpable apprehension by parents and other thinkers over the possibility of abuse of the doctrine of in loco parentis by some school officials that the doctrine's acceptance and relevance to maintaining discipline in the school is waning amid increasing advocacies for protection of fundamental human rights of individuals. The consequence is that students' behavioural problems such as fighting, stealing, cursing, bullying and examination malpractices has not only increased rapidly, but has also made the maintenance of discipline difficult for many school principals. The imperatives of analysing this situation from the standpoint of maintaining discipline in the schools, using the doctrine of in loco parentis as an anchor forms the thrust of this study.

\section{Statement of the Problem}

In recent time, there has been an unusual decline in academic performance of senior secondary school students in Delta State as evidenced in the massive failure of large number of candidates that sat for the Senior School Certificate Examination (SSCE) in the 2018/2019 session. This massive failure appears to be 
a sign of decline in the reading culture and learning habit of students, and may rightly be ascribable to the collapsing disciplinary system and control in the public secondary schools in the state. The reality that some people openly criticize the doctrine of in loco parentis (a doctrine that temporarily confers a portion of parental responsibilities to school officials) may have adversely affected the extent to which even principals stand in loco parentis , and by implication reduced the degree to which they can exercise their functions regarding discipline, safety, welfare and moral upbringing of students in the school.

Interestingly, the contentious aspect of the doctrine of in loco parentis that permits principals to administer corporal punishment on erring students has the force of law. Nevertheless, the growing criticisms against the doctrine for reason of giving too much right to principals and teachers to inflict punishment and cruel discipline may have discouraged educators from instilling discipline in the students. This is compounded by the rising students' activism and campaigns for human rights protection. These have probably put school principals at edge over how to perform their disciplinary functions without getting entangle in prolonged discipline-related litigations. All these are significant source of fear and administrative incapacity to maintain discipline in the school.

The consequence is that some school principals are now afraid of standing in loco parentis, with the result that good moral upbringing that marks the function of the school is fast disappearing from the school systems, while antisocial vices such as examination malpractices, violence and other forms of indiscipline are on the increase. Truly, some students even find it difficult to attend to school functions, obey school rules and respect their teachers because there are no sufficient behavioural checks in the school to regulate students' behaviours. Students that engage in these sorts of misbehaviours cannot perform well in their examinations. The researcher is worried about this situation because if it is not reversed by empowering educators to exercise reasonable discipline to correct students appropriately, the school may end up producing certificate holders that lack good moral standards and responsible character, and this study is worried about this trend.

\section{AIM AND OBJECTIVES OF THE STUDY}

The aim of this study was to investigate the application of the doctrine of in loco parentis in the maintenance of discipline in senior secondary schools in Delta State. Specifically, the objectives of this study were to:

1. find out the experiences of principals using in loco parentis in the maintenance of discipline in secondary schools in Delta State.

2. determine the ways the doctrine of in loco parentis aids principals in the maintenance of discipline in secondary schools in Delta Sate.

\section{Research Questions}

The following research questions guided the study.

4. What are the experiences of principals using in loco parentis in the maintenance of discipline in secondary schools in Delta State?

5. What are ways the doctrine of in loco parentis aids principals in the maintenance of discipline in secondary schools in Delta Sate?

\section{HYPOTHESES}

1. There is no significant difference between the mean ratings of male and female respondents on the experiences of principals using in loco parentis in the maintenance of discipline in secondary schools in Delta State.

2. There is no significant difference between the mean ratings of male and female respondents on the ways the doctrine of in loco parentis aids principals in the maintenance of discipline in secondary schools in Delta Sate.

\section{Methodology}

The study design of the study was descriptive. The population of the study was 427 principals (242 males and 185 females) distributed over the 427 public secondary schools in the 25 Local Government Areas in Delta State. The sample size was 214 principals, comprising 124 males and 90 female principals serving in public secondary schools in Delta State. The multistage and proportionate techniques were used to draw the sample. The instrument used to generate data was a self-structured 16 items questionnaire titled 'Application of the Doctrine of in loco parentis in Maintenance of Discipline by School Principals Questionnaire' 
Application of the doctrine of in loco parentis in the maintenance of discipline by secondary school principals in Delta State, Nigeria

(ADIMDSQ). It was divided into two sections, namely, Section A and Section B. Section A contained items seeking data on demographic variables of the respondents, while section B contained items assessing the two variables investigated in this study. Test re-test was used to establish the reliability co-efficient of the instrument at 0.80 . The modified four-point Likert-type rating scale of Strongly Agree (4 points), Agree (3 points), Disagree ( 2 points) and Strongly Disagree (1 point) was used to code responses. Items that scored $\mathrm{x}$ $\geq 2.50$ criteria were accepted whereas those below the criteria were deemed rejected by the respondents. The research questions were answered using simple average mean statistics, while the hypotheses were tested at 0.05 significant level using the z-test.

\section{AnSWERS to ReSEARCH Questions}

Research Question One: What are the experiences of principals using in loco parentis in the maintenance of discipline in secondary schools in Delta State?

Table1. Mean and average mean scores of male and female respondents on the experiences of principals using in loco parentis in the maintenance of discipline in secondary schools in Delta State

\begin{tabular}{|c|c|c|c|c|c|}
\hline \multirow[t]{2}{*}{$\mathbf{s} / \mathbf{n}$} & \multirow[t]{2}{*}{ Description of items } & \multicolumn{2}{|c|}{ Means of Principals } & \multirow{2}{*}{$\begin{array}{c}\text { Average } \\
\text { Mean }\end{array}$} & \multirow{2}{*}{ Remarks } \\
\hline & & $\underset{\bar{x}}{\text { Male }}$ & $\begin{array}{l}\text { Female } \\
\bar{x}\end{array}$ & & \\
\hline 1 & $\begin{array}{l}\text { Principals rely on in loco parentis to administer } \\
\text { discipline on disobedient students. }\end{array}$ & 2.65 & 2.71 & 2.68 & Agreed \\
\hline 2 & $\begin{array}{l}\text { Principals receive parental support in } \\
\text { administration of discipline on erring students. }\end{array}$ & 2.42 & 2.32 & 2.37 & Disagreed \\
\hline 3 & $\begin{array}{l}\text { Principals do not misuse the doctrine of in loco } \\
\text { parentis by abusing students. }\end{array}$ & 2.65 & 2.49 & 2.57 & Agreed \\
\hline 4 & $\begin{array}{l}\text { Principals administer discipline to disobedient } \\
\text { students without being harassed or intimidated by } \\
\text { parents. }\end{array}$ & 2.25 & 2.17 & 2.21 & Disagreed \\
\hline 5 & $\begin{array}{l}\text { Principals are at times assaulted by parents for } \\
\text { administering discipline on unruly students. }\end{array}$ & 2.96 & 2.50 & 2.73 & Agreed \\
\hline 6 & $\begin{array}{l}\text { Principals are hardly arrested by police officers } \\
\text { for punishing disobedient students. }\end{array}$ & 2.89 & 2.53 & 2.71 & Agreed \\
\hline 7 & $\begin{array}{l}\text { Principals are not often prosecuted in the law } \\
\text { court for punishing students. }\end{array}$ & 3.06 & 2.62 & 2.84 & Agreed \\
\hline 8 & $\begin{array}{l}\text { School principals are not often convicted in the } \\
\text { law court for punishing students. }\end{array}$ & 3.01 & 2.70 & 2.86 & Agreed \\
\hline & Aggregate & 2.74 & 2.51 & 2.63 & \\
\hline
\end{tabular}

In table 1 above is shown the mean and average mean scores of male and female respondents on the experiences of principals using in loco parentis in the maintenance of discipline in secondary schools in Rivers State. The analysis above reveals that statements in items 1, 3, 5, 6, 5, 7 and 8 were agreed, while items 2 and 4 were disagreed by the respondents, resulting aggregate average mean of 2.63, and thus establishes that principals experiences in the application of in loco parentis was moderate.

Research Question Two: What are ways the doctrine of in loco parentis aid principals in the maintenance of discipline in secondary schools in Delta Sate?

Table2. Mean and average mean scores of male and female respondents on the ways doctrine of in loco parentis aids principals in the maintenance of discipline in secondary schools in Delta Sate

\begin{tabular}{|c|c|c|c|c|c|}
\hline \multirow[t]{2}{*}{$\mathbf{s} / \mathbf{n}$} & \multirow[t]{2}{*}{ Description of items } & \multicolumn{2}{|c|}{ Means of Principals } & \multirow{2}{*}{$\begin{array}{c}\text { Average } \\
\text { Mean }\end{array}$} & \multirow{2}{*}{ Remarks } \\
\hline & & Male & Female & & \\
\hline 9 & $\begin{array}{l}\text { In loco parentis helps principals to administer discipline } \\
\text { on students. }\end{array}$ & 3.02 & 2.60 & 2.81 & Agreed \\
\hline 10 & $\begin{array}{l}\text { In loco parentis provides legal backing to for principals } \\
\text { to correct erring students. }\end{array}$ & 2.92 & 3.09 & 3.01 & Agreed \\
\hline 11 & $\begin{array}{l}\text { The doctrine of in loco parentis requires principals to } \\
\text { take responsibility for moral and character development } \\
\text { of students. }\end{array}$ & 2.73 & 2.57 & 2.65 & Agreed \\
\hline
\end{tabular}


Application of the doctrine of in loco parentis in the maintenance of discipline by secondary school principals in Delta State, Nigeria

\begin{tabular}{|l|l|c|c|c|c|}
\hline 12 & $\begin{array}{l}\text { Principals rely on the doctrine of in loco parentis to } \\
\text { make reasonable rules and regulation for guiding the } \\
\text { conducts of students in the school }\end{array}$ & 3.01 & 3.07 & 3.04 & Agreed \\
\hline 13 & $\begin{array}{l}\text { The doctrine of in loco parentis makes it necessary for } \\
\text { principals to device punitive and non-punitive measures } \\
\text { to discipline students in the school. }\end{array}$ & 3.03 & 3.01 & 3.02 & Agreed \\
\hline 14 & $\begin{array}{l}\text { The doctrine of in loco parentis imposes fiduciary duty } \\
\text { on principals to maintain conducive teaching and learning } \\
\text { environment in the school. }\end{array}$ & 2.68 & 3.14 & 2.91 & Agreed \\
\hline 15 & $\begin{array}{l}\text { In loco parentis requires principals to educate students to } \\
\text { obey school rules to avoid punishment. }\end{array}$ & 2.92 & 2.93 & 2.93 & Agreed \\
\hline & $\quad$ Aggregate & $\mathbf{2 . 9 0}$ & $\mathbf{2 . 9 2}$ & $\mathbf{2 . 9 2}$ & \\
\hline
\end{tabular}

In table 2 above is shown the mean and average mean scores of male and female respondents on the ways doctrine of in loco parentis aids principals in the maintenance of discipline in secondary schools in Rivers State. The analysis above revealed that all the items 9, 10,11, 12, 13, 14 and 15 were all agreed by the respondents, resulting in high aggregate mean score of 2.92, and thus establishes that all the statements constituted ways the doctrine of in loco parentis aids principals in the maintenance of discipline in secondary schools in Delta State.

\section{TEST OF HYPOTHESES}

Hypothesis One: There is no significant difference between the mean ratings of male and female respondents on the experiences of principals using in loco parentis in the maintenance of discipline in secondary schools in Delta State.

Table3. z-test analysis of the difference between male and female respondents on the experiences of principals using in loco parentis in the maintenance of discipline in secondary schools in Delta State

\begin{tabular}{|c|c|c|c|c|c|c|c|c|c|}
\hline S/No & $\begin{array}{c}\text { Comparing } \\
\text { Variables }\end{array}$ & $\mathbf{N}$ & Mean & SD & Df & z-cal & z-crit. & $\begin{array}{c}\text { Sig. } \\
\text { Level }\end{array}$ & Remark \\
\hline 1. & Male Principals & 124 & 2.74 & 0.72 & & & & & Significant \\
\hline 2. & Female Principals & 90 & 2.51 & 0.76 & 212 & 2.49 & \pm 1.96 & 0.05 & $\left(\mathrm{H}_{\mathrm{O}}\right.$ rejected $)$ \\
\hline
\end{tabular}

In table 3 , the mean scores of 2.74 for male and 2.51 for female respondents are not closely related. Hence, significant difference exited between the mean scores. Furthermore, at 212 degrees of freedom and at 0.05 level of significance, the z-calculated value of 2.49 was by far higher than the $\mathrm{z}$-critical value of \pm 1.96 . Consequently, since significant difference exited between the mean scores of male and female principals at 212 degrees of freedom and 0.05 significant level, and the calculated z-value was higher than the critical value, the researcher was constrained to reject the null hypothesis stated, and thus established that there was significant difference between the mean scores of male and female respondents on the experiences of principals using in loco parentis in the maintenance of discipline in secondary schools in Delta State.

Hypothesis Two: There is no significant difference between the mean ratings of male and female respondents on the ways the doctrine of in loco parentis aids principals in the maintenance of discipline in secondary schools in Delta Sate.

Table4. z-test analysis of the difference between male and female respondents on the ways the doctrine of in loco parentis aids principals in the maintenance of discipline in secondary schools in Delta

\begin{tabular}{|c|c|c|c|c|c|c|c|c|l|}
\hline S/No & $\begin{array}{c}\text { Comparing } \\
\text { Variables }\end{array}$ & N & Mean & SD & Df & z-cal & z-crit. & $\begin{array}{c}\text { Sig. } \\
\text { Level }\end{array}$ & Remark \\
\cline { 1 - 7 } 1. & Male Principals & 124 & 2.90 & 0.79 & \multirow{2}{*}{212} & 0.19 & \pm 1.96 & 0.05 & $\begin{array}{l}\text { Not Significant } \\
\left(\mathrm{H}_{\mathrm{O}} \text { accepted }\right)\end{array}$ \\
\hline 2. & Female Principals & 90 & 2.92 & 0.75 & 212 & \\
\hline
\end{tabular}

In table 4 , the mean scores of 2.90 for male and 2.92 for female respondents are closely related. Hence, no significant difference exited between the mean scores. Furthermore, at 212 degrees of freedom and at 0.05 level of significance, the z-calculated values of 0.19 was by lower than the $\mathrm{z}$-critical value of \pm 1.96 . Consequently, since no significant difference exited between the mean scores of male and female principals at 212 degrees of freedom and 0.05 significant level, and the calculated z-value was lower than the critical value, the researcher was constrained to accept the null hypothesis stated, and thus established that there was no significant difference between the mean scores of male and female respondents on the ways the 
Application of the doctrine of in loco parentis in the maintenance of discipline by secondary school principals in Delta State, Nigeria

doctrine of in loco parentis aids principals in the maintenance of discipline in secondary schools in Delta State.

\section{DisCUSSION OF FINDINGS AND IMPLICATIONS}

\section{The experiences of principals using in loco parentis in the maintenance of discipline in secondary schools in Rivers State}

As already established, this study showed that principals relied on the doctrine of in loco parentis to administer discipline on disobedient students. The study also showed that principals did not misuse the doctrine of in loco parentis by abusing students. These findings are consistent with Fayokun and Adedeji (2013), who reported a court case experience of a school principal who was charged to court for disciplining students that contravened school rules. The scholar further reported that the principal was acquitted by the presiding judge who cited the doctrine of in loco parentis as the constitutional basis under which the principal stood to discipline the student according to the school rules; the judge subsequently cleared the accused principal of all charges. This study finding however contradicted the observation of Peretomode (2004), who reviewed a court case of a teacher who abused the doctrine of in loco parentis by inflicting serious injuries on a student. The scholar continued that the parents of the injured student dragged the teacher to court where he was found guilty on some charges (including abuse of in loco parentis), and was subsequently fined for the offence, along with damages he had to pay to the injured student.

This study also showed that principals were assaulted by parents for administering discipline on unruly students. Further findings in this study showed that principals lacked parental support to discipline erring students. It was also found out that principals were harassed by students' parents or guardians for punishing disobedient students. This finding is in tandem with Kiwale (2017), who reported that some parents and guardians often thronged to the school to assault teachers for punishing their disobedient students under the doctrinal requirements of in loco parentis. This finding is partly consistent with the remarks of Alexander (1980), who stated that the circumstances under which the doctrine of in loco parents was instituted does no longer apply in full context, arguing that parents may have good reason to say no to punishment of their children, but that would be inconsistent with school organization, and perhaps a cog in the wheels of effective operation of schools because without rules, school cannot achieve its mandate; and rules are made to be obeyed, meaning that when it is disobeyed some sort of punishment will be administered to discourage further infractions. These findings and reports reveal that principals encounter different experiences in the course of performing their disciplinary responsibilities in school. It is therefore of no wonder that this study found out that there was significant difference between the mean scores of male and female principals on the experiences of principals using in loco parentis in the maintenance of discipline in secondary schools. Nakpodia (2012) reported that significant difference existed between the attitude of experienced instructors and less experienced instructors. The scholar further observed the existence of a significant relationship between the attitude of instructors standing in loco parentis in urban and rural schools in the performance of administrative responsibilities of standing in loco parentis in the state schools.

It is in this wisdom that Nakpodia (2011) encouraged all school principals in Nigeria to peruse and become conversant with national laws. The scholar particularly urged school leader to read section 37, 38 and 39 of 1999 and 1989 Nigeria Constitutions in order to be aware of their legal duties, rights, obligations and boundaries. Being knowledgeable in law will help them to know their right and left and thus become properly guided with skills and knowledge with which to handle indiscipline in respective school. Most states policies in administration of punitive punishment is sub-delegated to principal by School Board.(Peretomode, 2004), this implies that only the principal or his/her designate can administer corporal punishment on students. The design was to reduce the cases of teacher-student brutality and other unreasonable punishments that disregard the student's fundamental human rights, age, sex, health and magnitude of misbehaviour.

\section{Ways the doctrine of in loco parentis aids principals in the maintenance of discipline in secondary schools}

This study revealed the ways in loco parentis aids school principals in administration of discipline in secondary schools as thus; in loco parentis gave legal authority to principals to discipline students reasonably; it provided legal backings for principals to correct erring students; it required principals to take responsibility for moral and character developments of students in the school; and also it empowered 
principals to make reasonable rules and regulations for guiding the conducts of students in school. These findings corroborate the remarks of Nakpodia (2012), who observed that the doctrine of in loco parentis is well-entrenched and effective in Nigeria education system, adding that Nigerian laws consider educators as acting under in loco parentis in administration of reasonable discipline to correct students' misbehaviours.

The findings of this study further showed that in loco parentis empowers principals to make reasonable rules and regulations for guiding the conducts of students in school. Ndeto (2013) found out that school principals derive their powers to protect, care and love students from the doctrinal principle of in loco parentis, adding that the doctrine grants adequate powers to principals to make reasonable rules and regulations for guiding students behaviours and even teachers alike. This is in congruence with Biokoro (2019), who reported that adequate knowledge of education laws, including the sections covering inloco parentis, was strongly associated to effective discipline management in school.

Furthermore, the study revealed that there was no significant difference between the mean scores of male and female principals on the ways the doctrine of in loco parentis aids principals in the maintenance of discipline in secondary schools. This finding is inconsistent with Nakpodia (2012), who reported that attitude of instructors in large and small school over their standing in loco parentis in the discharge of their duties was insignificant.Corroborating this finding Fayokun and Adedeji (2013) school principals and teachers can be held accountable for certain actions and their inactions is circumstances that require answerability and liability. This is why it is necessary for school authorities to draft school rules to regulate learners' behaviours, and use the doctrinal tool administers reasonable discipline to promote order, tranquillity and peaceful school climate. This is because any excessive corporal assault or beating resulting in serious bruises and injuries is unjustifiable in law and contravene the absolute rights to life, security and well-being of a person, be it a child or an adult (Stuart, 2009).

The bottom line is that discipline must be reasonable, moderated and only intended to train, control and educate the child, otherwise any excessive punishment established in law court will lead to charges of cruelty and criminal liability, which upon conviction may lead to fines, jail term or greater consequences. However, in a situation in which the school principal fails to draft and enforce rules to prevent bullying, stealing, fighting, cheating, etc., or refused to remove hazardous objects and substances from the school premises, with the result that social disorder ensued in the school, leading to desperate situation in which some students get injured, the school authority may be held liable for negligence should the parents of the students who suffered injuries sue the school.

\section{CONCLUSiON}

Based on the findings, the study concludes that school principals moderately performed their disciplinary responsibilities standing in loco parentis. The study also concludes that principals encountered oppositions from parents in the application of in loco parentis to discipline students.

\section{RECOMMENDATIONS}

1. The government and Ministry of Education should sensitize parents on the need for them to desist from attacking principals and teachers when their children are reasonably disciplined in school.

2. Principals should ensure that school rules are reasonable and consistent with the constitution of the country.

3. The Ministry of Education should regularly organize trainings for principals and teachers respectively, in order to educate them properly on effective ways of administering discipline without hurting students psychologically

4. Principals should reasonably apply punitive discipline such as corporal punishment as such should be used only when necessary and in moderation when non-punitive approach has failed to address a given act of indiscipline.

\section{REFERENCES}

[1] Alexander, K. (1980). School law. West Publishing Co.

[2] Biokoro, O. B. (2019). Principals' knowledge of education law in secondary school administration in Delta and Bayelsa States, Nigeria. Journal of Law, Policy and Globalization, 89, 27-37 
Application of the doctrine of in loco parentis in the maintenance of discipline by secondary school principals in Delta State, Nigeria

[3] Ekanem, E.E. \& Edet, A.O. (2013). Effects of corporal punishment on disciplinary control of secondary school students in Calabar metropolis of Nigeria. Global Journal Of Educational Research, 12, 19-25

[4] Fayokun, K. O. \& Adedeji, S. O. (2013). Legal issues in educational management in Nigeria. Makerere Journal of Higher Education, 4(2), 187 - 202

[5] Federal Ministry of Education [FME] (2014). National policy of education. NERDC Press.

[6] Federal Republic of Nigeria (1999). The constitution of the Federal Republic of Nigeria. NERDCPress.

[7] Kiwale, A. J. (2017). Factors leading to indiscipline in secondary schools in Siha District Council, Tanzania. Unpolished dissertation submitted the Open University of Tanzania.

[8] Nakpodia, E. D. ( 2011). Analysis of cases of violation of students' rights in Delta State Secondary Schools, Nigeria. Prime Research Journals on Education, 1(3) 50 - 59.

[9] Nakpodia, E. D. ( 2012). Teachers' responsibilities in-loco-parentis in secondary schools in Abraka metropolis, Delta State, Nigeria. Global Journal of HUMAN SOCIAL SCIENCE Linguistics \& Education, 12 (11) 25-36

[10] Nakpodia, E.D. (2009). Perceptions of principals responsibilities in-loco-parentis in Nigerian Secondary Schools" International Journal of Educational Sciences, 1(2) 99 - 107.

[11] Ndeto, A. M. (2013). Effectiveness of school rules and regulations in enhancing discipline in public secondary schools in Kangundo Division, Machakos County, Kenya. Unpublished thesis submitted to the Catholic University of Eastern Africa.

[12] Nene, F. Z. (2013). The challenges of managing learner discipline: the case of two schools in Pinetown District. Unpublished dissertation submitted to the University of Kwazulu-Natal, South Africa.

[13] Nwabueze, A.I. \& Ihuoma, C.C. (2018).Implications for effective enforcement of education laws in the administration of secondary schools. International Journal of Studies in Education,15(3), 1-18

[14] Olaitan,T., Nayaya, M.A. \& Lukman, A.A (2013). Management of disciplinary problems in secondary schools: Jalingo Metropolis in Focus. Linguistics \& Education, 13 (14), 57-65.

[15] Peretomde, V. F. (2004). Educational Law and the Law Principles: Cases and Materials on Schools. International University Press.

[16] Stuart, S. (2009). In loco parentis in the public schools: Abused, confused and in need of change. University of Cincinnati Law Review, 78:969-1005.

Citation: Efeotor, I. E \& Kpee, G.G" Application of the doctrine of in loco parentis in the maintenance of discipline by secondary school principals in Delta State, Nigeria” International Journal of Humanities Social Sciences and Education (IJHSSE), vol 8, no. 7, 2021, pp. 192-201. doi: https://doi.org/10.20431/2349-0381.0807022.

Copyright: (C) 2021 Authors. This is an open-access article distributed under the terms of the Creative Commons Attribution License, which permits unrestricted use, distribution, and reproduction in any medium, provided the original author and source are credited. 